\title{
Emerin increase in regenerating muscle fibers
}

\author{
S. Squarzoni, ${ }^{1}$ P. Sabatelli, ${ }^{1}$ C. Capanni, ${ }^{1}$ G. Lattanzi, ${ }^{1}$ C. Rutigliano, ${ }^{2}$ M. Columbaro, ${ }^{2}$ E. Mattioli, ${ }^{2}$ \\ M. Rocca, ${ }^{3}$ N.M. Maraldi ${ }^{1,2,4}$ \\ ${ }^{1}$ ITOI-CNR, Unit of Bologna c/o Istituti Ortopedici Rizzoli, Bologna; 'Lab. Biologia Cellulare e Microscopia \\ Elettronica, Istituti Ortopedici Rizzoli, Bologna; ${ }^{3}$ Modulo Dipartimentale di Chirurgia Generale, Istituti \\ Ortopedici Rizzoli, Bologna; ${ }^{4}$ Dept. Scienze Anatomiche Umane e Fisiopatologia Apparato Locomotore, \\ University of Bologna, Italy
}

(C)2005, European Journal of Histochemistry

The fate of emerin during skeletal muscle regeneration was investigated in an animal model by means of crush injury. Immunofluorescence, immunoblotting and mRNA analysis demonstrated that emerin level is increased in regenerating rat muscle fibers with respect to normal mature myofibers. This finding suggests an involvement of emerin during the muscle fiber regeneration process, in analogy with its reported involvement in muscle cell differentiation in vitro. The impairment of skeletal muscle physiological regeneration or reorganization could be a possible pathogenetic mechanism for Emery Dreifuss muscular dystrophy.

Key words: emerin, skeletal muscle regeneration, nucleus, myonuclear domain, Emery-Dreifuss muscular dystrophy.

Correspondence: S. Squarzoni,

ITOI-CNR, v. Di Barbiano 1/10 c/o IOR, 40136 Bologna, Italy Tel. +39.051.6366768.

Fax. +39.051.583593.

E-mail: squarzoni@area.bo.cnr.it

Paper accepted on June 13, 2005

European Journal of Histochemistry

2005; vol. 49 issue 4 (Oct-Dec): 355-362
E merin is a ubiquitously expressed nuclear envelope protein, which is inserted in the inner nuclear membrane (Bione, 1994; Cartegni, 1997; Manilal, 1996; Nagano, 1996) and interacts with the nuclear lamina components (Clements, 2000; Fairley, 1999; Squarzoni, 2000; Wilson, 2000).

Emerin is encoded by the STA gene (chromosome $\mathrm{Xq}$ 28): mutations in this gene causing emerin absence or alteration are responsible for the $\mathrm{X}$ linked form of Emery-Dreifuss muscular dystrophy (EMD) (Bione, 1994), a syndrome characterized by slowly progressive muscle wasting and weakness, contractures of the elbows, Achille's tendons and post-cervical muscles. Cardiac conduction defect is also present in the patients and represents the most dangerous feature of EMD, since it can lead to heart block and sudden death even in the absence of skeletal muscle involvement; moreover, arrhythmia and sudden death have been reported also in female carriers (Bialer, 1991; Emery, 1989; Emery, 2000; Emery, 1966; Fishbein, 1993; Nagano, 2000).

Emerin localizes not only to the nuclear rim: an additional cytoplasmic positivity for emerin has also been described in some tissues (Nagano, 2000), in cultured cells and in myocardium (Cartegni, 1997; Lattanzi, 2000; Squarzoni, 1998). Emerin has been described in normal human circulating platelets and in the cytoplasm of their precursors, the megakaryocytes (Squarzoni, 1998).

On the basis of emerin localization to the nuclear lamina, and of its relation with other nuclear components, possible involvement in gene expression or in structural roles have been hypothesized for the emerin function (reviewed in Maraldi, 2002; Wilson, 2000). In the absence of emerin, structural alterations have been described at the nuclear lamina (Fidzianska, 1998; Ognibene, 1999), where important interactions between chromatin and nuclear matrix proteins take place (Hozak, 1995; Maraldi, 2003; Wilson, 2000). Similarly, in the 
autosomal dominant form of EMD, structural alterations have been found at the nuclear periphery, which are analogous to those found in the absence of emerin (Sabatelli, 2001; Sullivan, 1999). As the autosomal dominant EMD form is due to mutations in the gene encoding for the nuclear lamina protein lamin A/C (Bonne, 1999), which interact with emerin (Clements, 2000; Fairley, 1999), a general involvement of the peripheral nuclear matrix in the pathogenesis of both EMD forms, more probably functional than structural, may be hypothesized.

In this regard, the upregulation of emerin during the myogenic differentiation process of cultured muscle cells has been demonstrated (Lattanzi, 2000), suggesting that emerin may be necessary at early stages of the myogenic differentiation. These data support the hypothesis of a functional role of emerin in muscle cells, which is probably more evident when transcriptional activity of the muscle cell nuclei is increased. Besides the myogenic differentiation, a second important dynamic phase of the skeletal muscle cell nucleus is the muscle fiber regeneration process. The aim of this study is to analyze at mRNA and protein levels, the behavior of emerin during the regeneration of skeletal muscle, induced experimentally in an animal model. A comparison is also attempted with emerin mRNA levels in muscle and myocardium at the neonatal stage of development.

\section{Materials and methods}

\section{Animals}

Five male Wistar rats $(350 \pm 50 \mathrm{~g}$ b.w. $)$, under general anesthesia, were submitted to an extensive crush injury at the level of the rectus femoris of the right hind limb. Rectus femoris of the controlateral leg was left intact to be used as a control. General anaesthesia was induced by intramuscular administration of $87 \mathrm{mg} / \mathrm{kg}$ ketamine and $13 \mathrm{mg} / \mathrm{kg}$ xylazine. An incision of the skin was made on the lateral side of the thigh. After having smoothly dissected the central third of the muscle, a small pair of forceps was inserted to clamp and crush all the belly of the rectus femoris. Compression was uniformly applied for three minutes on the whole area grasped by the forceps, but the longitudinal continuity of the muscle was maintained as the forceps was closed at the second sear, thus avoiding to resect the tissue. The muscle crush was about
$16 \mathrm{~mm}$ long and $2.5 \mathrm{~mm}$ wide, and extended throughout the depth of the muscle. At the end of compression the forceps was removed and the skin wound was sutured with separate silk stitches. After 5-11 days the rats were euthanised under general anesthesia, and both the crushed and control muscles were collected. Skeletal muscle and myocardium samples obtained from neonatal rats (euthanised under general anesthesia for other experiments) were used for comparing emerin mRNA level with the regenerating and control samples of adult rats. The European and Italian laws on animal experimentation were strictly followed during the entire study and the animal research protocol was approved by the responsible public authorities, as requested by the Italian Law according to the EC rules (Law by Decree, 27 January, 1992 no. 116).

\section{Antibodies}

Anti-emerin antibody (monoclonal, Novocastra UK) was used 1:100 for Western blotting and 1:10 for immunofluorescence analysis. Anti-foetal MHC (monoclonal Novocastra, UK) was used 1:100 for Western blotting and 1:10 for immunofluorescence analysis; anti-caveolin 3 (monoclonal, Transduction Laboratories, USA) was used 1:5000 for Western blotting and 1:100 for immunofluorescence analysis. Anti-CD 8 FITC-conjugated (Serotec, UK) was used 1: 100 overnight.

\section{Tissue preparation}

Skeletal muscle samples were dissected from the rectus femori of both the injured and the control legs, as well as of neonatal rats, and immediately frozen in melting isopenthane. Hearts were also collected from neonatal rats and frozen as described. For protein electrophoresis and mRNA analysis, frozen tissue cryostat sections were used: morphological controls were made on the sections by light microscopy in order to check the absence of mononuclear cell infiltrate.

\section{mRNA analysis}

Total RNA was isolated from frozen muscle: 100 cryostat sections $10 \mu \mathrm{m}$ thick were used for each sample. Extraction was performed using SV Total RNA Isolation System (Promega Corporation, Madison, WI), according to manufacturer's specifications; the density was measured at $260 \mathrm{~nm}$ and RNA stored at $-80^{\circ} \mathrm{C}$. 


\section{Semiquantitative RT-PCR}

Each reverse transcription ( $R T$ ) reaction was performed on 200 ng total RNA with Ready-To-Go RT-PCR Beads (Amersham Pharmacia Biotech, UK) using the Two Step protocol, as instructed. First strand cDNA was synthesized using oligo (dT) primer. After $30 \mathrm{~min}$ at $42^{\circ} \mathrm{C}$, RT reactions were incubated at $95^{\circ} \mathrm{C}$ for $10 \mathrm{~min}$ and cooled on ice for 5 min to inactivate reverse transcriptase.

All PCRs were performed in the same tubes as $\mathrm{RT}$, in $50 \mu \mathrm{L}$ total volume. Final concentrations were 1,5 mM MgCl $2,0,2 \mathrm{mM}$ of each dNTP, 0,01 mM DIG-11-dUTP (Roche Diagnostics GmbH, Mannheim, Germany) and 2,0 units of Taq DNA polymerase in the $60 \mathrm{mM} \mathrm{KCl}$ and $10 \mathrm{mM}$ Tris- $\mathrm{HCl}$ buffer $(\mathrm{pH} \mathrm{9,0)}$.

Emerin primers sequences were designed as follows: forward primer, 5'-ATGGACGACTATGCGGTTTTG-3'; reverse primer, 5'-GGTTGCCTTCTTCAGCTTGTA-3', which result in a 762 bp product. $\alpha$-Actin primers sequences were designed as follows: forward primer, 5'-TCATGAAGTGTGACGTTGACATCCGT-3', reverse primer, 5'CCTAGAAGCATTTGCGGTGCACGATG-3', which result in a 285 bp product.

Cycles conditions for emerin were: denaturation $94^{\circ} \mathrm{C}$ for $1 \mathrm{~min}$; annealing $55^{\circ} \mathrm{C}$ for $1 \mathrm{~min}$; and extension $72^{\circ} \mathrm{C}$ for $1 \mathrm{~min}$ ( 30 amplification cycles). After completing the reaction cycles, the PCRs were maintained at $72^{\circ} \mathrm{C}$ for $10 \mathrm{~min}$ and then a $4^{\circ} \mathrm{C}$ until analyses. Cycles conditions for $\alpha$-Actin were denaturation $94^{\circ} \mathrm{C}$ for $30 \mathrm{sec}$; annealing $65^{\circ} \mathrm{C}$ for 1 min; and extension $68^{\circ} \mathrm{C}$ for 2 min (30 amplification cycles). After completing the reaction cycles, the PCRs were maintained at $68^{\circ} \mathrm{C}$ for $7 \mathrm{~min}$ and then a $4^{\circ} \mathrm{C}$ until analyses.

Semi-quantitative analyses were carried out as described (Streit, 1998; Yamamoto, 1996) except that the detection and quantification of PCR products was performed with DIG Luminescent Detection Kit (Roche Diagnostics GmbH, Mannheim, Germany). Products for $\alpha$-Actin were run on the same gel as the PCR products for emerin; $25 \mu \mathrm{L}$ of each reaction was electrophoresed on a $1 \%$ agarose gel, then the gel was electro-blotted onto a nylon membrane (Nytran, Schleicher \& Schuell, Dassel, Germany) overnight. After 2 hours at $80^{\circ} \mathrm{C}$, the filter was washed in 0,1 M maleic acid/0,3\% Tween-20 and the DIG-labeled PCRs were detected using anti-digoxigenin, Fab fragments conjugated to alkaline phosphatase, and then visualized with the chemiluminescence substrate CSPD. DNA molecular weight marker VI DIG-labeled (Roche Diagnostics GmbH, Mannheim, Germany) was used as DNA size marker.

\section{Protein electrophoresis and Western blot analysis}

Muscle samples consisted of different series of 50 cryostat sections, $10 \mu \mathrm{m}$ thick, cut from the rectus femori muscle of both the treated and untreated rat legs. The sections were collected in an Eppendorf tube and were lysed as previously described (Manilal, 1996).

For the electrophoresis, a $1.5 \mathrm{~mm}$ thick SDS polyacrilamide minigel (Mini-protean II; Bio-Rad, Richmond, CA, USA) was used. The resolving gel contained $15 \%$ acrylamide for emerin and caveolin 3, and $6 \%$ acrylamide for foetal MHC. Proteins were transferred onto nitrocellulose membranes (Hybond-C; Amersham, UK); these were incubated with $4 \%$ powdered milk, $0.05 \%$ Tween 20 in 10 $\mathrm{mM}$ Tris $\mathrm{pH} 8,150 \mathrm{mM} \mathrm{NaCl}$ (TBST) for $1 \mathrm{~h}$ at room temperature to saturate non-specific binding sites. Immunoreaction with primary monoclonal antibodies, diluted as described before, was performed for $\mathrm{l} \mathrm{h}$ at room temperature. A second incubation was carried out for 45 min with a goat antimouse IgG-HRP (Amersham, UK) which was diluted 1:5000 in TBST. The blot was developed by the Amersham $\mathrm{ECL}^{\circledR}$ detection system.

\section{Immuno-histochemistry}

Skeletal muscle transverse cryostat serial sections ( $7 \mu \mathrm{m}$ thick) were cut at the border of the regenerating areas in order to examine both regenerating and intact fibers in the same microscopic field. The sections were first tested with the anti-CD 8 fluorescent antibody to exclude the presence of inflammatory cells. Serial sections were incubated with primary antibodies (anti-emerin, anti-MHC, anti-caveolin 3, respectively), diluted as described before with phosphate buffer-saline (PBS) - $2 \%$ bovine serum albumine (BSA), for 1 hour. After washing with PBS containing $0.1 \%$ Tween 20 , the samples were incubated with TRITC or FITC-conjugated secondary antibodies (Dako) diluted 1:100 in PBS - 2\% BSA for 1 hour, at room temperature, in the dark. Control sections were incubated in the absence of primary antibody. Observation was done with a Nikon E 600 epifluorescence microscope. 

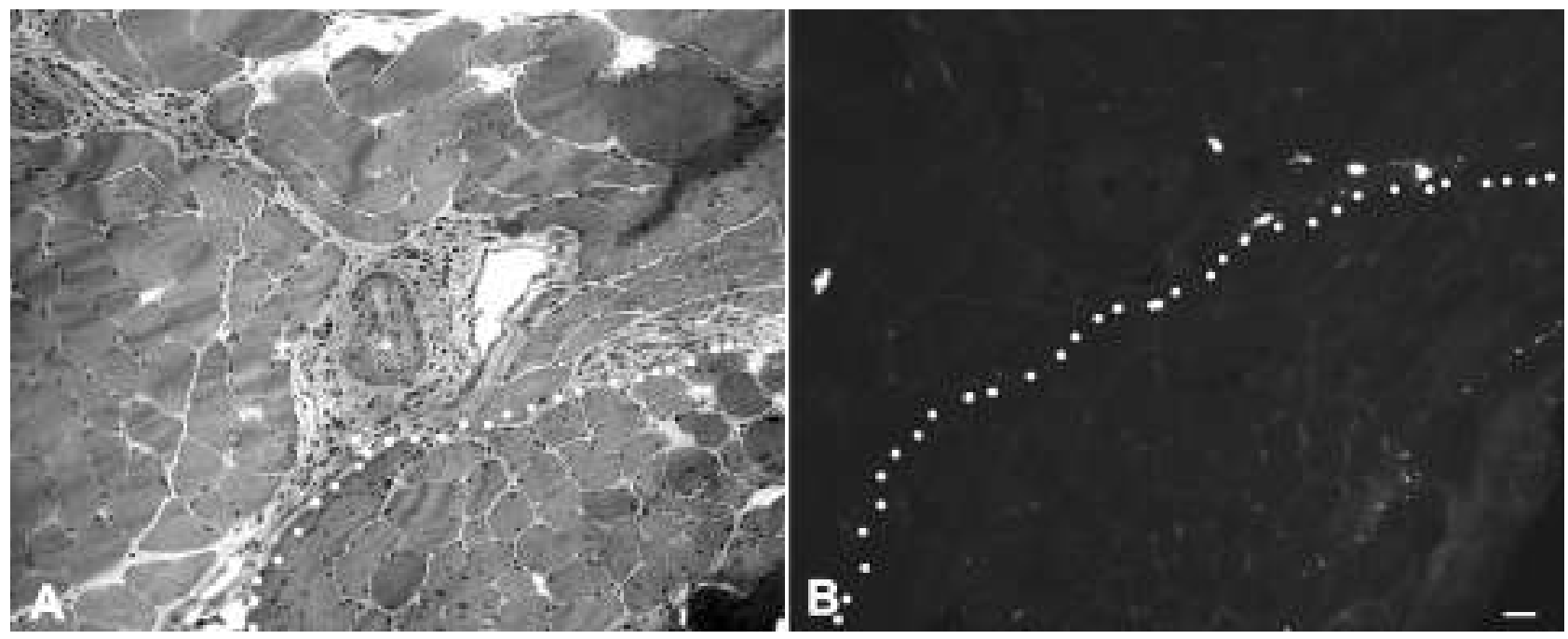

Figure 1. Transverse muscle section; A) hematoxylin - eosin staining. The dotted line represents the border between regenerating area (right lower corner) and normal muscle fibers. Regenerating fibers show variable size and several internal nuclei. B) a contiguous sections incubated with anti-CD 8 antibody shows overall absence of inflammatory cells; only few CD 8-positive cells are visible near a blood vessel, outside the regenerating area. Bar: $50 \mu \mathrm{m}$.

\section{Results}

At the light microscope, the areas of muscular tissue containing regenerating fibers were easily detected in the sections because the muscle fibers appeared smaller than normal and had a variable diameter; central nuclei were also frequently visible inside the fibers; at the border of the regenerating area, normal non-regenerating muscle fibers were distinctly visible.

At day 9 of regeneration, no mononuclear cell infiltrate was present (Figures 1, 4d); we considered this time step for appropriate molecular, biochemical and immunohistochemical analyses of the nuclear protein emerin.

\section{mRNA analysis}

The analysis performed by semi-quantitative RTPCR methods, showed an increased level of emerin mRNA in the samples obtained from regenerating muscle, compared to control samples (Figure 2). mRNA level in regenerating adult skeletal muscle approached, but did not reach, the amount present in neonatal rat tissues. RT-PCR amplification reaction for actin mRNA showed a similar product amount in each sample.

\section{Immunoblotting}

Western blot analysis showed that in the lysates of the sections obtained from the regenerating muscle, an increased emerin content was present, in

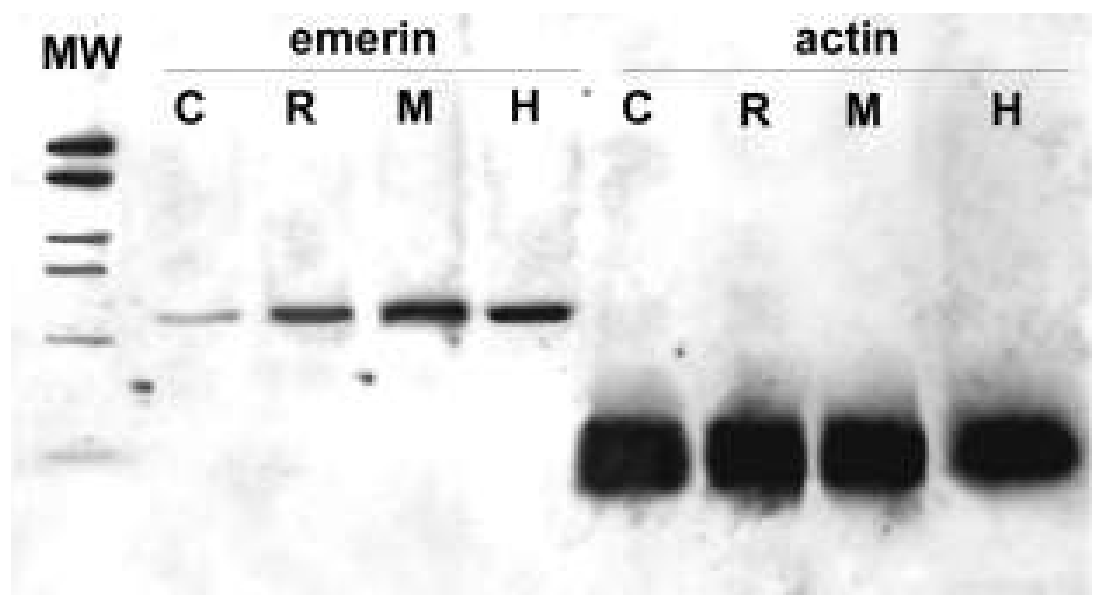

Figure 2. Semi-quantitative RT-PCR analysis. Emerin: amplification product of emerin mRNA. Actin: amplification product of actin mRNA. C: adult rat control muscle, R: adult rat regenerating muscle, M: neonatal rat muscle, H: neonatal rat heart. MW: molecolar weight marker VI. Emerin mRNA amount is increased in regenerating muscle $(R)$, compared with control (C). Higher amounts are present in neonatal muscle $(M)$ and heart $(H)$. Amplification products of actin mRNA display the same levels in all samples. 


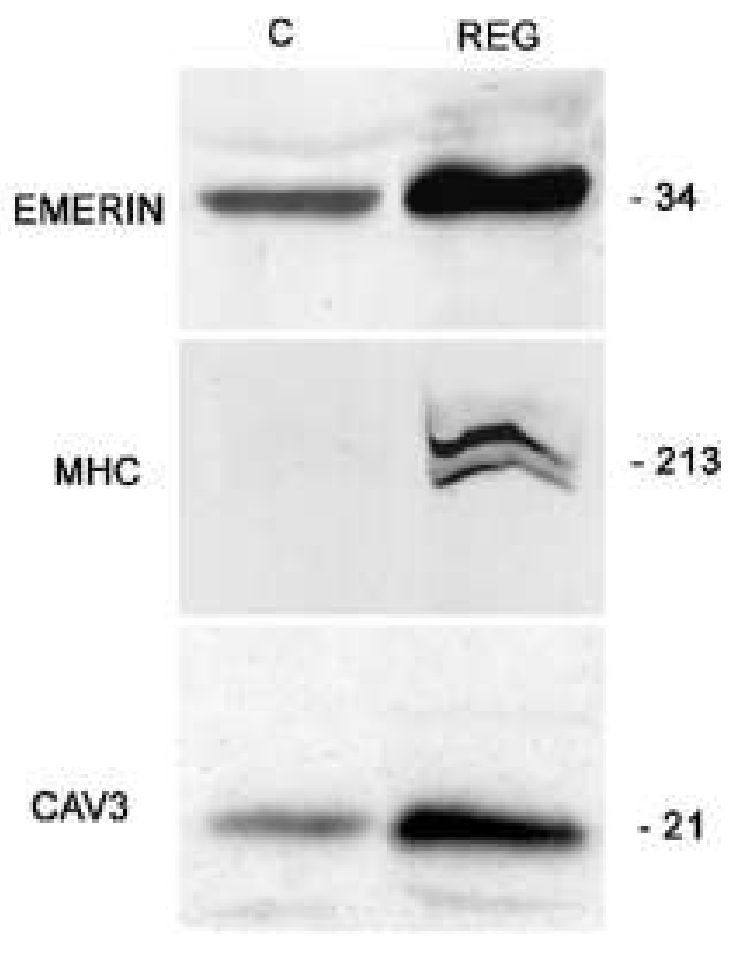

Figure 3. Western blot analysis of control (C) and regenerating (REG) muscle lysates. Regenerating muscle shows increase in emerin amount, paralleled by the detection of MHC and increased levels of caveolin 3.

comparison with lysates of sections from the control muscle. The samples with increased emerin contained also foetal MHC and had an increase in caveolin. (Figure 3 ).

\section{Immunofluorescence}

When the sections were labeled with the antiemerin antibody, the nuclei within the smaller and irregular fibers as well as the centrally located nuclei (i.e. in the regenerating areas), showed an intense annular fluorescence, markedly higher than the signal observed in nuclei of fibers with a regular architecture, with no size variation and without central nuclei, visible at the border of the regenerating areas (Figure $4 a$ ).

Serial sectioning of the same fibers in which the emerin signal was increased, allowed us to demonstrate a positive cytoplasmic labeling with antifoetal MHC (Figure 4b); the fluorescence for caveolin 3 at the plasmalemma was also increased in these fibers, compared to the adjacent muscle tissue, and was detectable in the cytoplasm too (Figure 4c). Hematoxylin - eosin staining of a contiguous section showed a typical regenerating mor- phological pattern, with fiber diameter variability and central nuclei (Figure $4 d$ ). These results confirmed that the fibers where emerin was increased, were effectively regenerating. Control sections, incubated in the absence of primary antibodies, were not labeled (data not shown).

\section{Discussion}

A postulated function of emerin is to stabilize the nuclear membrane and provide a structural support in environments in which the nucleus is subjected to mechanical stress; nevertheless, an increased fragility of the muscle cells nucleus in the absence of emerin (i.e. in Emery-Dreyfuss dystrophy) cannot itself explain phenomena such as the selective damage to definite muscles. On the other hand, functional roles of emerin have been also hypothesized (reviewed in Maraldi, 2002; Wilson, 2000; Ostlund, 1999).

Our results demonstrate that emerin expression is increased in regenerating rat muscle fibers both at transcription and translation levels; this is confirmed by mRNA, immunoblotting and immunohistochemical analysis of regenerating muscle fibers obtained experimentally in rat quadriceps femori muscle. All nuclei in the regenerating fibers show an increased peripheral, emerin-specific fluorescence in comparison with the non-regenerating ones. Accordingly, detection of centrally located nuclei, of foetal MHC and of increased caveolin 3 fluorescence (Niiyama, 1999) in the fibers with enhanced nuclear fluorescence, ensures that these fibers are effectively regenerating. The increase in emerin level shown by Western blotting is paralleled by $\mathrm{MHC}$ and caveolin 3 increase. At the molecular level, mRNA analysis indicates an increase in trascriptional activity in the regenerating muscle samples. Morphological analysis of the muscle sections used for preparing the tissue lysates, excluded the possibility that the emerin increase detected by Western blotting is caused by the presence of nuclei from circulating inflammatory cells.

These data may be interpreted by suggesting the hypothesis of an emerin role during the skeletal muscle fiber maturation. An analogous upregulation of emerin expression has been demonstrated at the early stages of the differentiation process in cultured $\mathrm{C} 2 \mathrm{C} 12$ and primary muscle cells (Lattanzi, 2000). In contrast with the reported emerin presence in the cytoplasm of cultured differentiated myotubes (Lattanzi, 2000), emerin is not expressed 

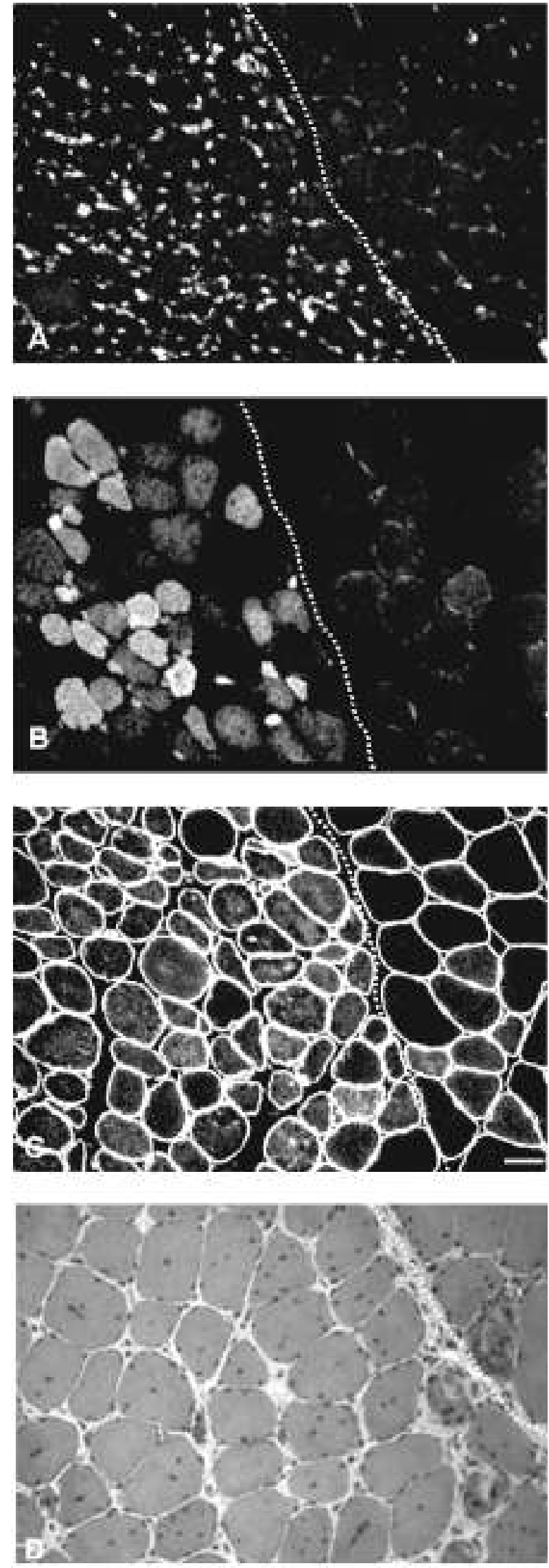

in the cytoplasm of rat regenerating skeletal muscle fiber. This suggests the possibility that a complex mechanism exists, which might control emerin expression variation at different stages of the muscle maturation process. In this regard, it is interesting to note that emerin mRNA is expressed at lower levels in adult rat skeletal muscle than in neonatal skeletal muscle and myocardium, and that muscle regeneration restores mRNA expression levels similar to the neonatal condition.

The process of muscle regeneration in adults requires a rapid growth of muscle fibers, i.e. a dynamic phase during which virtually all the transcription loci are activated (Newlands, 1998). Nuclear microenvironments have an important role in the integration of regulatory signals (Stein, 2004; Maraldi, 1998). Moreover, a role in the regulation of gene transcription has been suggested for emerin (Maraldi, 1998; Wilson, 2000; Maraldi, 2003; Ostlund, 1999) on the basis of its relationship with nuclear scaffold proteins such as lamin A/C (which is responsible for the autosomal dominant form of EMD), and of its interactions with chromatin binding proteins like BAF (Lee, 2001) and HA95 (Martins, 2000).

The up-regulation of emerin expression we observed in muscle fibers undergoing maturation and organization of new cytoplasmic myonuclear domains (the amount of cytoplasm per nucleus) (Allen, 1999), could support the hypothesis of an involvement of emerin in the modulation of muscle specific genes transcription. Our findings may also suggest a probable pathogenetic mechanism for $E M D$, based on the impairment of the muscle fiber regeneration and satellite cells differentiation processes in the absence of emerin. It is interesting to note that satellite cells activation happens fre-

Figure 4 (left column). Transverse muscle serial sections, immunofluorescence. The dotted line represents the border between regenerating area (left) and normal muscle fibers (right). A) Anti-emerin, B) anti-MHC, C) anti-caveolin 3, D) hematoxylin-eosin staining. All the three antibodies show an increased signal in the regenerating areas. The labeling intensity of anti-emerin monoclonal antibody $(A)$ in normal fibers, on the right, appears weaker compared to the high signal detected on the left of the section, which reveals an increased emerin expression during regeneration. MHC expression (B) is evident in regenerating fibers (on the left), where it varies according with maturation of the newly formed fibers. Caveolin 3 fluorescence (C) is increased in the plasmalemma of regenerating fibers (on the left) where it is detected inside the cytoplasm too. D) hematoxylin - eosin staining showing the morphology of the section series; regenerating fibers show variable size and several internal nuclei. Bar: $50 \mu \mathrm{m}$. 
quently, as it has been reported to be triggered by several factors also in the absence of myofiber death, i.e.: by muscle overwork, exercise, stretching, hormones etc. (Bischoff, 1990; Hikida, 1997; Newlands, 1998; Noakes, 1987); satellite cells activation and fusion have been reported to be involved in postnatal muscle maturation and growth, i.e. in processes resulting in an increased number of myofiber nuclei (Allen, 1999). Finally, it has been reported that myonuclei turnover might occur without involving satellite cells activation (Schmalbruch, 2000). All these phenomena require a continuous organization of existing and new myonuclear domains, whose size is reported to remain constant during postnatal growth and hypertrophy, so that the nuclear-to-cytoplasmic volume ratio is maintained in the polynucleated muscle fiber. Emerin might be considered a candidate member of a protein family involved in these processes.

The absence of alterations in the embryonic muscle development in EMD patients, as well as the onset of this disease during childhood or later, might be due to the differences in the mechanisms which drive the formation of skeletal muscle fibers, being the fusion of myoblasts for the production of multinucleated myofibers during embryogenesis a distinct event with respect to fusion of satellite cells with the mature myofibers in the postnatal growth/repair process (Horsley, 2001).

\section{Acknowledgments}

This work was supported by grants from: Italian Ministry of Health $n^{\circ}$ 2003/123, Fondazione Carisbo Italy, MIUR FIRB n ${ }^{\circ}$ RBNE01JJ45_005 and MIUR COFIN 2004. The Authors are grateful to Mr. A. Valmori for technical assistance.

\section{References}

Allen DL, Roy RR, Edgerton VR. Myonuclear domains in muscle adaptation and disease. Muscle and Nerve 1999; 22:1350-60.

Bialer MG, McDaniel NL, Kelly TE. Progression of cardiac disease in Emery-Dreifuss muscular dystrophy. Clin Cardiol 1991; 14:411-6.

Bione S, Maestrini E, Rivella S, Mancini M, Regis S, Romeo G, et al. Identification of a novel $X$-linked gene responsible for EmeryDreifuss muscular dystrophy. Nature Genetics 1994; 8:323-32.

Bischoff R. Cell cycle commitment of rat muscle satellite cells $\mathrm{J}$ Cell Biol 1990; 111:201-7.

Bonne G, Raffaele Di Barletta M, Varnous S, Becane HM, Hammouda $E H$, Merlini L, et al. Mutations in the gene encoding lamin $A / C$ cause autosomal dominant Emery-Dreifuss muscular dystrophy. Nat Genet 1999; 21:285-8.

Cartegni L, Raffaele Di Barletta M, Barresi R, Squarzoni S, Sabatelli $P$, Maraldi NM, et al. Heart specific localization of emerin: new insights into Emery-Dreifuss muscular dystrophy. Hum Mol Genet 1997; 6:2257-64.

Clements L, Manilal S, Love DR, Morris GE. Direct interaction between emerin and lamin A. Biochem Biophys Res Commun. 2000; 267:709-14.

Emery AEH. Emery-Dreifuss syndrome. J Med Genet 1989; 26:63741.

Emery AEH. Emery-Dreifuss muscular dystrophy - a 40 year retrospective. Neuromuscul Disord 2000;10:2

Emery AEH, Dreifuss FE Unusual type of benign X-linked muscular dystrophy. J Neurol Neurosurg Psychiatry 1966; 29:338-42.

Fairley EAL, Kendrick-Jones J, Ellis JA. The Emery-Dreifuss muscular dystrophy phenotype arises from aberrant targeting and binding of emerin at the inner nuclear membrane. J Cell Sci 1999; 112:712582.

Fidzianska A, Toniolo D, Hausmanowa-Petrusewicz I. Ultrastructural abnormality of sarcolemmal nuclei in Emery-Dreifuss muscular dystrophy (EDMD). J Neurol Sci 1998; 159:88-93.

Fishbein MC, Siegel RJ, Thompson CE, Hopkins LC. Sudden death of a carrier of $\mathrm{X}$-linked Emery-Dreifuss muscular dystrophy. Ann Intern Med 1993; 119:900-5.

Hikida RS, Van Nostran S, Murray JD, Staron RS, Gordon SE, Kraemer WJ. Myonuclear loss in atrophied soleus muscle fibers. Anat Rec 1997; 247:350-4.

Horsley V, Friday BB, Matteson S, Kegley KM, Gephart J, Pavlath GK. Regulation of the Growth of Multinucleated Muscle Cells by an NFATC2-dependent Pathway. J Cell Biol 2001; 53:329-38.

Hozak P, Sasseville AM, Raymond Y, Cook PR. Lamin proteins form an internal nucleoskeleton as well as a peripheral lamina in human cells. J Cell Sci 1995; 108:635-44.

Lattanzi G, Ognibene A, Sabatelli P, Capanni C, Toniolo D, Columbaro $\mathrm{M}$, et al. Emerin expression at the early stages of myogenic differentiation. Differentiation 2000; 66:208-17.

Lee KK, Haraguchi T, Lee RS, Koujin T, Hiraoka Y, Wilson KL. Distinct functional domains in emerin bind lamin A and DNA-bridging protein BAF. J Cell Sci 2001; 114:4567-73.

Manilal S, Nguyen TM, Sewry C, Morris GE. The Emery-Dreifuss muscular dystrophy protein, emerin, is a nuclear membrane protein. Hum Mol Gen 1996; 5:801-8.

Maraldi NM, Zini N, Santi S, Ognibene A, Rizzoli R, Mazzotti G, Manzoli FA. Cytochemistry of the functional domains of the nucleus in normal and in pathologic conditions. Eur J Histochem 1998; 42:41-53.

Maraldi NM, Squarzoni S, Sabatelli P, Lattanzi G, Ognibene A, Manzoli FA. Emery-Dreifuss muscular dystrophy, nuclear signaling and chromatin remodeling. Adv Enzym Reg 2002; 42:1-18.

Maraldi NM, Lattanzi G, Sabatelli P, Ognibene A, Columbaro M, Capanni $C$, et al. Immunocyto-chemistry of nuclear domains and Emery-Dreifuss muscular dystrophy pathophysiology. Eur J Histochem 2003; 47:3-16.

Martins SB, Eide T, Steene RL, Jansen T, Skålhegg B, Collas P. HA95 is a protein of the nuclear matrix regulating nuclear envelope dynamics. J Cell Sci 2000; 113:3703-13.

Nagano A, Arahata K. Nuclear envelope proteins and associated diseases. Curr Opin Neurol 2000; 13:533-9.

Nagano A, Koga R, Ogawa M, Kurano Y, Kawada J, Okada R, et al. Emerin deficiency at the nuclear membrane in patients with EmeryDreifuss muscular dystrophy. Nature Genetics 1996; 12:254-9.

Newlands S, Levitt LK, Robinson CS, Karpf ABC, Hodgson VRM, Wade RP, Hardeman EC. Transcription occurs in pulses in muscle fibers. Gen \& Develop 1998; 12:2748-58.

Niiyama T, Higuchi I, Maruyama I, Osame M. Expression of thrombomodulin, caveolin-3, and desmin on muscle fibers in neuromuscular diseases. Muscle Nerve 1999; 22:1713-6.

Noakes TD. Effect of exercise on serum enzyme activities in humans. Sports Med 1987; 4:245-67.

Ognibene A, Sabatelli P, Petrini S, Squarzoni S, Riccio M, Santi S, et al. Nuclear changes in a case of $X$-linked Emery-Dreifuss muscular dystrophy. Muscle Nerve 1999; 22:864-9.

Ostlund C, Ellenberg J, Hallberg E, Lippincott-Schwartz J, Worman $\mathrm{HJ}$. Intracellular trafficking of emerin, the Emery-Dreifuss muscular dystrophy protein. J Cell Sci 1999; 112:1709-19. 
Sabatelli P, Lattanzi G, Ognibene A, Columbaro M, Capanni C, Merlini $L$, Maraldi NM, Squarzoni S. Nuclear alterations in autosomaldominant Emery-Dreifuss muscular dystrophy. Muscle Nerve 2001; 24:826-9.

Schmalbruch $H$, Lewis DM. Dynamics of nuclei of muscle cell fibers and connective tissue cells in normal and denervated rat muscles. Muscle \& Nerve 2000; 23:617-26.

Squarzoni S, Sabatelli P, Capanni C, Petrini S, Ognibene A, Toniolo D, et al. Emerin presence in platelets. Acta Neuropathol 2000; 100:291-8.

Squarzoni S, Sabatelli $\mathrm{P}$, Ognibene A, Toniolo D, Cartegni L, Cobianchi $F$ et al. Immunocytochemical detection of emerin within the nuclear matrix. Neuromuscular Disorders 1998; 8:338-44.

Stein GS, Stein JL, Lian JB, Van Wijnen AJ, Montecino M, Javed A, et al. Nuclear microenvironments: an architectural platform for the convergence and integration of transcriptional regulatory signals.
Eur J Histochem 2004; 48:65-76.

Streit WJ, Semple-Rowland SL, Hurley SD, Miller RC, Popovich PG, Stokes BT. Cytokine mRNA profiles in contused spinal cord and axotomized facial nucleus suggest a beneficial role for inflammation and gliosis. Exp Neurol 1998; 152:74-87.

Sullivan T, Escalante-Alcalde D, Bhatt $H$, Anver M, Bhat N, Nagashima $K$, et al. Loss of A-type lamin expression compromises nuclear envelope integrity leading to muscular dystrophy. J Cell Biol 1999; 147:913-20.

Wilson KL. The nuclear envelope, muscular dystrophy and gene expression. Trends Cell Biol 2000; 10:125-9.

Yamamoto M, Sobue G, Yamamoto K, Terao S, Mitsuma T. Expression of mRNAs for neurotrophic factors (NGF, BDNF, NT-3, and GDNF) and their receptors ( 755 NGFR, trkA, trkB, and trkC) in the adult human peripheral nervous system and non-neural tissues. Neurochem Res 1996; 21:929-38. 